www.jmscr.igmpublication.org

Impact Factor 5.84

Index Copernicus Value: 83.27

ISSN (e)-2347-176x ISSN (p) 2455-0450

crossref DOI: _https://dx.doi.org/10.18535/jmscr/v5i5.35

\title{
Socio-demographic correlates of HIV-TB Co-infected Patients Attending ART Centre of Jharkhand
}

\author{
Authors \\ Dr Vidyasagar ${ }^{1}$, Dr Abhishek Kumar ${ }^{2}$, Dr Vivek Kashyap ${ }^{3}$, Dr Nishant Kumar ${ }^{4}$, \\ Dr Nisha Shrivastava ${ }^{5}$ \\ ${ }^{1}$ Associate Professor, ${ }^{2}$ Junior Resident, ${ }^{3}$ Prof. and Head, Dept. of PSM, Rajendra Institute of Medical \\ Sciences, Ranchi, ${ }^{4,5}$ Junior Resident, Dept. of ENT, RIMS, Ranchi \\ Corresponding Author \\ Dr Abhishek Kumar
}

3A/301, Maurya Residency, Nalanda Colony, Bariatu, Ranchi-834009, Jharkhand, India

Email:ak07mail@gmail.com

\begin{abstract}
Background: The HIV epidemic has posed a major challenge to control tuberculosis (TB) across the world. $H I V$ and TB both primarily affect people in their most productive years of life.

Objectives: This study was done aiming to describe the socio-demographic profile of HIV-TB Co-infected patients attending ART Centre of RIMS, Ranchi and also the type of TB and CD4 count in HIV-TB Coinfected patients.

Methods: This was a record based cross sectional study. Data of all HIV-TB co-infected patients attending ART Centre of RIMS, Ranchi was collected from ART Register which came out to be 80 patients. Total study duration was 3 months (June 2016 to August 2016). Templates were generated in MS excel sheet and analysis was done using SPSS software.

Results \& Conclusion: On analyzing 80 subjects it was found that majority were males $(62,77.5 \%)$ with most commonly affected age group being 21-40 years (49,61.2\%). Smear positive pulmonary TB was most common type of TB $(34,42.5 \%)$ with most patients having CD4 count $<500(75,93.75 \%)$. TB in HIV infected patients is more common in males in their most productive years of life. Extra pulmonary TB being second most common after smear positive pulmonary $T B$.
\end{abstract}

Keywords: Profile, HIV-TB Co-infection, CD4 Count.

\section{Introduction}

While HIV and tuberculosis (TB) can individually be the major causes for concern as stand-alone public health threats, the combination of the two has proven to have a far greater impact on the epidemiologic progression and consequently on the impact it has on the global health scene. The dual infection has been termed "accursed duet" ${ }^{[1]}$.
Patients with HIV infection are more likely to have active TB by a factor of 100 when compared with an HIV negative population ${ }^{[2]}$. HIV and TB both are grave situation and their association becomes even more dangerous.

HIV increases a person's susceptibility to TB infection. The risk of activation of dormant TB is about $10 \%$ per year in HIV positive patients in 
contrast to $10 \%$ lifetime risk in HIV negative patients. TB is the opportunistic infection that most frequently kills HIV-positive people. The HIV virus damages body's natural defences, the immune system and accelerates the speed at which tuberculosis progresses from a harmless infection to life threatening condition ${ }^{[3]}$.

Epidemiological Impact - HIV \& TB interact in several ways ${ }^{[4]}$ - Reactivation of latent infection: HIV-positive individuals have 25-30 times more chances of developing tuberculosis than those of HIV-negative individuals, because immune system does not work effectively in HIV-positive individuals and tuberculosis bacilli multiply rapidly, Primary infection: New tubercular infection in HIV-positive people can progress to active disease very quickly, Recurring infection: HIV-positive people who are cured of tuberculosis may be more at risk of developing tuberculosis again. However it is not clear whether this is because of re-infection or relapse \& In the community: More people are getting infections and they are infecting others. TB-HIV co-infected people suffer additional discrimination. So community education is needed to increase awareness that TB is curable, so that people no longer remain infectious to others.

Even in HIV-positive cases, TB can be cured if diagnosed in time and treated properly. With correct TB treatment, HIV positive patients having TB can gain average two additional years of life. India is the highest TB burden country in the world in terms of absolute number of incident cases that occur each year.

According to WHO Global TB report 2016 an estimated 10.4 million people developed TB in 2015 and 1.4 million died from the disease and an additional 400000 deaths were due to HIV-TB[5]. This study aims to describe the socio-demographic profile of HIV-TB Co-infected patients attending ART Centre of RIMS, Ranchi and to describe the type of TB and CD4 count in HIV-TB Co-infected patients.

\section{Material and Methods}

This was a record based cross sectional study done at ART Centre of RIMS, Ranchi. The total duration of study was 3 months (June 2016 to August 2016). Data for describing sociodemographic profile, type of TB and CD4 counts were collected from the register of HIV-TB patients at ART Centre of RIMS, Ranchi for the year 2015. This accounted to a total of 80 . Templates were generated in MS excel sheet and analysis was done using SPSS software (version 20).

\section{Results}

Out of 80 patients most common affected age group was $20-40$ years $(61.25 \%)$ followed by 40 60 years $(30 \%)$. Males accounted for $77.5 \%$ of patients. More than half of the patients $(62.5 \%)$ were from rural area and majority $(83.75 \%)$ were from non-tribal ethnicity.

Sputum Smear Positive Pulmonary TB (SS +ve PTB) is most commonly found $(42.4 \%)$ followed by Extra Pulmonary TB (EPTB).

Majority (93.75\%) have CD - 4 Count $<500 /$ cumm.

More than $3 / 4^{\text {th }}(85 \%)$ patients were on DOTS. On applying chi - square test we found no association between socio - demographic profile and type of TB, DOTS therapy status and CD -4 count among patients (as p-value $>0.05$ ).

Table 1: Socio-demographic profile

\begin{tabular}{|l|c|c|c|}
\hline & & $\begin{array}{c}\text { Frequency } \\
(\mathrm{n}=80)\end{array}$ & $\begin{array}{c}\text { Percentage } \\
(\%)\end{array}$ \\
\hline \multirow{4}{*}{ Age (In Years) } & $<20$ & 07 & 8.75 \\
\cline { 2 - 4 } & $21-40$ & 49 & 61.25 \\
\cline { 2 - 4 } & $41-60$ & 24 & 30 \\
\hline \multirow{3}{*}{ Gender } & Male & 62 & 77.5 \\
\cline { 2 - 4 } & Female & 18 & 22.5 \\
\hline \multirow{2}{*}{ Residence } & Rural & 50 & 62.5 \\
\cline { 2 - 4 } & Urban & 30 & 37.5 \\
\hline \multirow{2}{*}{ Ethnicity } & Tribal & 13 & 16.25 \\
\cline { 2 - 4 } & Non - Tribal & 67 & 83.75 \\
\hline
\end{tabular}

Table 2: Type of TB found among HIV-TB Coinfected patients

\begin{tabular}{|l|c|c|}
\hline Type of TB & $\begin{array}{c}\text { Frequency } \\
(\mathrm{n}=80)\end{array}$ & $\begin{array}{c}\text { Percentage } \\
(\%)\end{array}$ \\
\hline SS +ve PTB & 34 & 42.5 \\
\hline SS -ve PTB & 19 & 23.8 \\
\hline EPTB & 27 & 33.7 \\
\hline
\end{tabular}


Table 3: CD - 4 Count status of HIV-TB Coinfected patients

\begin{tabular}{|l|c|c|}
\hline $\begin{array}{l}\mathrm{CD}-4 \text { Count Status } \\
\text { (in per cumm) }\end{array}$ & $\begin{array}{c}\text { Frequency } \\
(\mathrm{n}=80)\end{array}$ & $\begin{array}{c}\text { Percentage } \\
(\%)\end{array}$ \\
\hline$<500$ & 75 & 93.75 \\
\hline$>500$ & 05 & 6.25 \\
\hline
\end{tabular}

Table 4: Status of DOTS among HIV-TB Coinfected patients

\begin{tabular}{|l|c|c|}
\hline DOTS Status & $\begin{array}{c}\text { Frequency } \\
(\mathrm{n}=80)\end{array}$ & $\begin{array}{c}\text { Percentage } \\
(\%)\end{array}$ \\
\hline On DOTS & 68 & 85 \\
\hline Not on DOTS & 12 & 15 \\
\hline
\end{tabular}

Table 5 : Association between socio-demographic profile and type of TB among patients

\begin{tabular}{|c|c|c|c|c|c|}
\hline \multirow{2}{*}{$\begin{array}{l}\text { Socio-- } \\
\text { demographic } \\
\text { profile }\end{array}$} & & \multicolumn{3}{|c|}{ Type of TB } & \multirow{2}{*}{$\begin{array}{c}\mathrm{p}- \\
\text { value }\end{array}$} \\
\hline & & $\begin{array}{c}\text { SS +ve } \\
\text { PTB }\end{array}$ & $\begin{array}{c}\text { SS -ve } \\
\text { PTB }\end{array}$ & EPTB & \\
\hline \multirow[t]{2}{*}{ Gender } & Male & 30 & 15 & 17 & \multirow[t]{2}{*}{0.168} \\
\hline & Female & 5 & 4 & 9 & \\
\hline \multirow[t]{2}{*}{ Ethnicity } & Tribal & 7 & 4 & 4 & \multirow[t]{2}{*}{0.295} \\
\hline & $\begin{array}{l}\text { Non- } \\
\text { Tribal }\end{array}$ & 28 & 15 & 22 & \\
\hline \multirow[t]{3}{*}{ Age group } & $<20$ yrs & 3 & 3 & 1 & \multirow[t]{3}{*}{0.461} \\
\hline & $21-40$ yrs & 20 & 9 & 20 & \\
\hline & $41-60$ yrs & 11 & 7 & 6 & \\
\hline \multirow[t]{2}{*}{ Residence } & Rural & 24 & 12 & 14 & \multirow[t]{2}{*}{0.500} \\
\hline & Urban & 12 & 7 & 11 & \\
\hline
\end{tabular}

Table 6: Association between socio-demographic profile and CD-4 count among patients

\begin{tabular}{|l|c|c|c|c|}
\hline \multirow{2}{*}{$\begin{array}{l}\text { Socio- } \\
\text { demographic } \\
\text { profile }\end{array}$} & & \multicolumn{2}{|c|}{$\mathrm{CD}-4$ count } & \multirow{2}{*}{$\begin{array}{c}\mathrm{p}- \\
\text { value }\end{array}$} \\
\cline { 3 - 4 } & & $\begin{array}{c}< \\
500 / \text { cumm }\end{array}$ & $\begin{array}{c}> \\
500 / \text { cumm }\end{array}$ & \\
\hline \multirow{2}{*}{ Gender } & Male & 58 & 4 & \multirow{2}{*}{0.890} \\
\cline { 2 - 4 } & Female & 17 & 1 & \\
\hline \multirow{2}{*}{ Ethnicity } & Tribal & 15 & 0 & \multirow{2}{*}{0.267} \\
\cline { 2 - 4 } & Non - Tribal & 60 & 5 & \\
\hline \multirow{2}{*}{ Residence } & $<20$ yrs & 6 & 1 & \multirow{2}{*}{0.882} \\
\cline { 2 - 4 } & $21-40$ yrs & 47 & 3 & \\
\cline { 2 - 4 } & $41-60$ yrs & 22 & 1 & \multirow{2}{*}{0.043} \\
\cline { 2 - 4 } & Rural & 49 & 4 & \\
\hline
\end{tabular}

Table 7: Association between socio-demographic profile and DOTS therapy status among patients

\begin{tabular}{|l|c|c|c|c|}
\hline \multirow{2}{*}{$\begin{array}{l}\text { Socio- } \\
\text { demographic } \\
\text { profile }\end{array}$} & & \multicolumn{2}{|c|}{ DOTS Therapy Status } & \multirow{2}{*}{$\begin{array}{c}\mathrm{p}- \\
\text { value }\end{array}$} \\
\cline { 3 - 4 } & & $\begin{array}{c}\text { On } \\
\text { DOTS }\end{array}$ & $\begin{array}{c}\text { Not on } \\
\text { DOTS }\end{array}$ & \\
\hline \multirow{2}{*}{ Gender } & Male & 51 & 11 & \multirow{2}{*}{0.202} \\
\cline { 2 - 4 } & Female & 17 & 1 & \\
\hline \multirow{2}{*}{ Age group } & Tribal & 14 & 1 & \multirow{2}{*}{0.316} \\
\cline { 2 - 4 } & Non - Tribal & 54 & 11 & \\
\cline { 2 - 4 } & $21-40$ yrs & 4 & 0 & \multirow{2}{*}{0.398} \\
\cline { 2 - 4 } & $41-60$ yrs & 21 & 3 & \\
\hline Residence & Rural & 42 & 8 & \multirow{2}{*}{0.746} \\
\cline { 2 - 4 } & Urban & 26 & 4 & \\
\hline
\end{tabular}

\section{Discussions}

More than $2 / 3^{\text {rd }}$ of the patients with HIV-TB coinfection were male and from non-tribal ethnicity belonging to rural areas.

Most commonly affected age group was $20-40$ years.

Most common type of TB found among patients was SS +ve PTB followed by EPTB and among PTB patients SS + PTB is more common than SS - PTB.

In a study done by R. Bahl, B. Singh and R. Singh in Jammu it was found that majority (> 75\%) of patients with HIV-TB were in age group of $21-$ 40 years. Female to male ratio was 2:1 ${ }^{[6]}$.

In a study done in Vadodra Gujrat by Ragini Ghia et. al. It was found that $68.7 \%$ patients were male and about $82.5 \%$ belonged to age group of $15-$ 50 years ${ }^{[7]}$.

Study at Abuja, Nigeria done by Jamda et. al. Showed that $57 \%$ patients were male and $71.4 \%$ patients completed their treatment ${ }^{[8]}$.

\section{Conclusions}

TB in HIV infected patients is more common in males in their most productive years of life. Extra pulmonary TB being second most common after smear positive pulmonary TB. Majority of PTB co-infected patients were having baseline CD4 count $<500 /$ cumm.

\section{Conflicts of interest}

There are no conflicts of interests.

\section{Ethical Approval}

The study was approved by Institutional Ethics Committee.

\section{References}

1. Jaiswal RK, Srivastav S, Mahajan $H$. Socio demographic profile of TB-HIV coinfected patients in Bundelkhand Region, Uttar-Pradesh. Natl J Med Res. 2012;2:149-51.

2. Longo Dan L, Fauci Anthony S, Kasper Dennis L, Hauser Stephen L. Harrison's 
Principles of Internal Medicine, $18^{\text {th }}$ edition, page 1548 .

3. WHO (1996) TB Groups At Risk, WHO Report on the Tuberculosis Epidemic, Geneva

4. AIDS Action, Asia-Pacific edition, The international newsletter on HIV/AIDS prevention and cure, AHRTAG Issue 30, January - March 1996.

5. www.who.int/gho/tb/en/

6. R. Bahl, B. Singh, R. Singh, Prevalance of HIV Infection Among Patients of Pulmonary Tuberculosis Attending Chest Disease Hospital, Jammu, Indian Journal of Community Medicine2007;32(4):288289

7. Ragini Ghiya, Eknath Naik, Beatu Cesanas, Ricardo Izurieta, Yogesh Marfatia, Clinico-epidemiological Profile of HIV/THB Co-infected Patients in Vadodra, Gujarat2009;30(1): 10-15

8. Jamda et al, Treatment Outcome of Patients Co-infected with Tuberculosis and HIV in Abuja, Nigeria2014;11(2): 57-61. 